\title{
ANALISIS PENGARUH KEBIJAKAN KEUANGAN DAN TATA KELOLA TERHADAP NILAI PERUSAHAAN INDUSTRI MANUFAKTUR YANG TERCATAT DI BURSA EFEK INDONESIA
}

\author{
ANALYSIS OF THE EFFECT OF FINANCIAL POLICY AND GOVERNANCE \\ ON THE RECORDED MANUFACTURING INDUSTRY \\ IN INDONESIA EXCHANGE
}

\author{
Sudirman $^{1}$, Maryam $^{2}$ \\ Pendidikan Agama Islam, Universitas Indonesia Timur \\ ${ }^{1}$ (Sudirmanabdi@gmail.com), ${ }^{2}$ (maryam.mary7741@yahoo.com)
}

\begin{abstract}
ABSTRAK
Peningkatan nilai perusahaan mempunyai ketergantungan dari tingkat pertumbuhan perusahaan. Perusahaan yang selalu menstabilkan pertumbuhan perusahaannya selalu berupaya untuk menjaga pertumbuhan penjualan, pertumbuhan aktiva dan pertumbuhan laba.Tujuan penelitian ini untuk menganalisis pengaruh kebijakan keuangan terhadap nilai perusahaan. Populasi dalam penelitian ini adalah perusahaan industri manufaktur yang tercatat di bursa efek Indonesia sebanyak 100 perusahaan. Sampel dalam penelitian ini adalah 20 perusahaan industri manufaktur berdasarkan pengelompokan dalam Indonesia Capital Market Directory (ICMD) yang menerbitkan laporan keuangannya secara kontinu selama empat tahun berturut-turut, yaitu, Tahun 2014 sampai dengan Tahun 2018, laporan keuangan berakhir 31 Desember, Perusahaan harus tidak menunjukkan adanya saldo total ekuitas dan laba yang negatif pada laporan keuangannya, tetap aktif dalam perdagangan Bursa Efek Indonesia selama periode Tahun 2014 sampai dengan Tahun 2018. Keputusan investasi mempunyai pengaruh negatif dan tidak signifikan terhadap nilai perusahaan. Berarti keputusan investasi yang diambil manajer belum layak dalam menciptakan nilai bagi para pemegang saham perusahaan. Keputusan pendanaan mempunyai pengaruh positif dan tidak signifikan terhadap nilai perusahaan. Artinya, keputusan yang diambil manajer sudah layak dalam menentukan penciptaan nilai bagi perusahaan walaupun sangat belum signifikan. Kebijakan deviden mempunyai pengaruh negatif dan signifikan terhadap nilai perusahaan. Artinya perusahaan telah menerapkan kebijakan yang cukup layak untuk menciptakan nilai bagi para investor dan pemegang saham perusahaan. Tata kelola mempunyai pengaruh positif dan tidak signifikan terhadap nilai perusahaan. Ini berarti tata kelola belum dijalankan sebagai sistem yang layak dalam menghasilkan nilai saham total aktiva, nilai saham total ekuitas dan nilai pasar perusahaan.
\end{abstract}

Kata Kunci: Kebijakan Keuangan, Tata Kelola, dan Nilai Perusahaan

\begin{abstract}
Increasing the value of the company has a dependency of the company's growth rate. Companies that always stabilize the growth of their companies always strive to maintain sales growth, asset growth and profit growth. The purpose of this study is to analyze the effect of financial policy on firm value. The population in this study is 100 manufacturing companies listed on the Indonesia stock exchange. The sample in this study is 20 manufacturing industry companies based on grouping in the Indonesia Capital Market Directory (ICMD) which publishes its financial statements continuously for four consecutive years, that is from 2014 to 2018, the financial statements end December 31, the company must not shows that there is a negative total balance of equity and profit on its financial statements, which remains active
\end{abstract}


in the trading of the Indonesia Stock Exchange during the period 2014 to 2018. Investment decisions have a negative and not significant effect on the value of the company. Means that investment decisions taken by managers are not feasible in creating value for the company's shareholders. Funding decisions have a positive and not significant effect on firm value. That is the decision taken by the manager is appropriate in determining the value creation for the company even though it is not yet significant. Dividend policy has a negative and significant effect on firm value. This means that the company has implemented a decent enough policy to create value for investors and corporate shareholders. Governance has a positive and not significant effect on company value. This means that governance has not been implemented as a viable system in producing the total stock value of assets, total stock value of equity and the market value of the company.

Keywords: Financial Policy, Governance, and Company Value

\section{PENDAHULUAN}

Memahami pentingnya pertumbuhan dan nilai perusahaan industri manufaktur yang tercatat di BEI, secara langsung dan tidak langsung dipengaruhi oleh kebijakan keuangan dan tata kelola. Kebijakan keuangan dalam hal ini adalah keputusan investasi, keputusan pendanaan dan kebijakan dividen.

Fenomena mengenai kebijakan keuangan pada industri manufaktur yang tercatat di BEI menunjukkan adanya pengambilan keputusan investasi yang belum layak berdasarkan nilai buku aktiva tetap, harga penutupan saham dengan total ekuitas, harga penutupan saham dengan total aktiva, nilai buku aktiva tetap dengan total aktiva, serta nilai buku aktiva tetap dengan harga saham. Keputusan investasi yang belum layak memberikan pengaruh terhadap pertumbuhan perusahaan. Hal ini relevan dengan teori investment dari Morgan (2018:12) yang menyatakan bahwa kebijakan keuangan tergambar pada keputusan investasi dalam menentukan pertumbuhan dan nilai perusahaan. Kebijakan investasi yang harus diperhatikan oleh manajer dalam mengambil kebijakan keuangan dilihat dari nilai buku aktiva tetap, harga penutupan saham dengan total ekuitas, harga penutupan saham dengan total aktiva, nilai buku aktiva tetap dengan total aktiva, serta nilai buku aktiva tetap dengan harga saham.
Terlihat berdasarkan fenomena keputusan pendanaan, terlihat pengambilan keputusan atas kebijakan keuangan masih belum layak berdasarkan total hutang dibagi total ekuitas, total hutang dibagi total aktiva, total hutang jangka panjang dibagi total ekuitas dan total hutang dibagi jumlah saham. Hal ini relevan dengan teori capital dari Struss (2011:85) yang menyatakan bahwa keputusan pendanaan ditentukan oleh keberadaan modal perusahaan yang dihitung melalui total hutang dibagi total ekuitas, total hutang dibagi total aktiva, total hutang jangka panjang dibagi total ekuitas dan total hutang dibagi jumlah saham.

\section{METODE}

Data keuangan yang digunakan merupakan data sekunder yang diperoleh dari Indonesia Capital Market Directory (ICMD) Jakarta tahun 2014 - 2018 selama 4 tahun dan data lainnya pada Website Jakarta Stock Exchange Jakarta dan data statistik serta laporan perkembangan perekonomian Indonesia dengan tujuan mencegah terjadinya keunikan hasil pada tahun tertentu saja. Data yang dibutuhkan dalam penelitian ini adalah nilai buku aktiva tetap (fixed assets) dan total aktiva (total assets), jumlah saham yang beredar dan harga penutupan saham, proporsi ekuitas dan total ekuitas, laba per lembar saham dan laba perusahaan. Total hutang jangka panjang dan total hutang, nilai dividen per lembar saham, jumlah saham yang dimiliki perusahaan, total saham yang beredar, jumlah saham 
yang dimiliki manajer, proporsi dewan komisaris, anggota dewan komisaris yang berasal dari luar perusahaan, jumlah anggota dewan audit, jumlah penjualan, dan konsentrasi kepemilikan saham.

Populasi penelitian ini adalah perusahaan-perusahaan industri manufaktur yang tercatat di Bursa Efek Indonesia. Pemilihan perusahaan-perusahaan industri manufaktur yang tercatat di Bursa Efek Indonesia sebagai obyek penelitian karena data laporan keuangan perusahaan tercatat telah tersedia sehingga mudah mengaksesnya dan data tersebut telah diaudit akuntan publik.

Jumlah perusahaan yang tercatat dalam Bursa Efek Indonesia sampai dengan Desember 2018 sebanyak 396 perusahaan yang termasuk perusahaan industri manufaktur 158 perusahaan namun yang masuk dalam kriteria sebanyak 20 perusahaan sehingga jumlah sampel yang sesuai kriteria sebanyak 20 perusahaan dengan laporan keuangan selama 4 tahun sehingga ada 100 perusahaan sampel dengan rincian perusahaan sampel:

Tabel 1 . Populasi dan Sampel Penelitian

\begin{tabular}{clc}
\hline No & \multicolumn{1}{c}{ Industri Manufaktur } & Sampel (n) \\
\hline 1 & PT. Tempo Scan Pasific Tbk. & 5 \\
2 & PT. Lion Metal Works Tbk. & 5 \\
3 & PT. Darya Varia Laboratoria Tbk. & 5 \\
4 & PT. Lautan Lus Tbk. & 5 \\
5 & PT. Colorpak Indonesia & 5 \\
6 & PT. Akr Corporindo (Aneka Kimia Raya) Tbk. & 5 \\
7 & PT. Sepatu Bata Tbk. & 5 \\
8 & PT. Gudang Garam Tbk. & 5 \\
9 & PT. Multi Bintang Indonesia Tbk. & 5 \\
10 & PT. Fast Food Indonesia Tbk. & 5 \\
11 & PT. Goodyear Indonesia Tbk. & 5 \\
12 & PT. United Tractors Tbk. & 5 \\
13 & PT. Sumi Indonesia Kabel Tbk. & 5 \\
14 & PT. Tunas Ridean Tbk. & 5 \\
15 & PT. Merck Indonesia Tbk. & 5 \\
16 & PT. Metrodata Electronic Tbk. & 5 \\
17 & PT. Indocemen Tunggal Perkasa Tbk. & 5 \\
18 & PT. Supreme Cable Manufacturing \& Commerce Tbk. & 5 \\
19 & PT. Unilever Indonesia Tbk. & 5 \\
20 & PT. Astra GraphiaTbk. & 5 \\
\hline & $\quad$ Jumlah sampel (n) & 100 \\
\hline
\end{tabular}

Analisis Inferensial SEM (Structural Equation Modeling)

Structural Equation Model (SEM) adalah teknik analisis statistik yang mengkombinasikan beberapa aspek yang terdapat pada analisis jalur dan analisis faktor konfirmatori untuk mengestimasi beberapa persamaan secara simultan. Model persamaan struktural (Structural Equation Modeling) merupakan generasi kedua teknik analisis multivariate yang memungkinkan peneliti untuk menguji hubungan antara variabel yang kompleks baik recursive maupun non-recursive untuk memperoleh gambaran menyeluruh mengenai keseluruhan model (Ghozali, 2005).

\section{Pengujian Validitas dan Reliabilitas Data}

Pengujian validitas adalah penelitian yang dilakukan untuk menentukan apakah suatu indikator, valid atau tidak dapat dilihat 
dari hasil uji t yaitu jika nilai t-hitung lebih besar dari 1.96 (t-hitung > 1.96) berarti bahwa indikator yang diukur dinyatakan valid.

Pengujian reliabilitas dalam penelitian ini dengan melihat nilai alpha Cronbach, apabila alpha Cronbach $(\alpha)$ lebih dari 0.60 maka data penelitian dianggap cukup baik dan reliable untuk digunakan sebagai input dalam proses pengolahan data guna menguji hipotesis penelitian (Maholtra, 2017).

\section{HASIL DAN PEMBAHASAN}

Memahami pentingnya pertumbuhan dan nilai perusahaan industri manufaktur yang tercatat di BEI, secara langsung dan tidak langsung dipengaruhi oleh kebijakan keuangan dan tata kelola. Kebijakan keuangan dalam hal ini adalah keputusan investasi, keputusan pendanaan dan kebijakan dividen. Berikut ditunjukkan data perusahaan manufaktur selama tahun 2014 sampai dengan 2018 sebagai berikut:

Tabel 2. Perkembangan Investasi, Pendanaan, dan Dividen Perusahaan Manufaktur Tahun $2014-2018$

\begin{tabular}{cccccc}
\hline Keterangan & 2014 & 2015 & 2016 & 2017 & 2018 \\
\hline Investasi & $36,5 \%$ & $45,8 \%$ & $62,6 \%$ & $68,9 \%$ & $75,5 \%$ \\
\hline Pendanaan & $42,4 \%$ & $34,8 \%$ & $32,3 \%$ & $56,8 \%$ & $66,1 \%$ \\
\hline Dividen & $56,0 \%$ & $65,5 \%$ & $51,0 \%$ & $74,5 \%$ & $77,2 \%$ \\
\hline
\end{tabular}

Berdasarkan hasil penelitian dari masingmasing variabel yang diamati pada perusahaan industri manufaktur yang tercatat di BEI, data perkembangan rasio masing-masing variabel sebagai berikut:

\section{Keputusan Investasi (X1)}

Indikator rasio nilai buku aktiva tetap terhadap nilai buku aktiva (X1.1) menurun dari Tahun 2014 sebesar 35,16 ke tahun 2015 menjadi 34,96 kemudian naik dari tahun 2015 ke tahun 2016 dan 2017 masingmasing 35,78 dan 37,35 turun menjadi 36,31 di tahun 2018. Dari rata-rata selama empat tahun sebesar 35,91, ini memperlihatkan hampir berada pada sekitar rata-rata dengan makna bahwa nilai buku aktiva sebesar $35,91 \%$ dari nilai buku aktiva perusahaan industri sampel.

Indikator jumlah saham beredar dikali harga penutupan saham terhadap total ekuitas (X1.2) naik dari tahun 2014 sebesar 259,39 ke tahun 2015 senilai 305,12, tahun 2015 ke tahun 2016 menurun dari 305,12 menjadi 154,03 kemudian naik dari tahun 2017 dan 2018 masing-masing menjadi 313,74 dan 347,07 . Rata-rata selama empat tahun sebesar 274,87. Ini menunjukkan bahwa nilai jumlah saham beredar dikali harga penutupan saham 2,74 kali dari total ekuitas perusahaan industri manufaktur yang menjadi sampel.

Indikator pertambahan nilai aktiva tetap tahunan terhadap aset (X1.3) naik dari tahun 2014 sebesar 206,39 ke tahun 2015 senilai 240,07, tahun 2015 ke tahun 2016 menurun dari 204,07 menjadi 162,44 kemudian naik di tahun 2017 dan 2018 masing-masing menjadi 265,47 dan 298,89. Rata-rata selama empat tahun sebesar 234,72 . Ini menunjukkan bahwa nilai total aktiva dikurangi total ekuitas ditambah jumlah saham beredar dikali harga penutupan saham 2,34 kali dari total aset perusahaan industri manufaktur yang menjadi sampel.

Indikator pertambahan aktiva tetap tahunan terhadap total asset (X1.4) naik dari tahun 2014 sebesar 9,35 berturut-turut ke tahun 2015 dan 2016 senilai 18,13 dan 30,74 kemudian menurun di tahun 2017 dan 2018 masing-masing 10,37 dan 9,26. Rata-rata selama empat tahun sebesar 15,59. Ini 
menunjukkan bahwa nilai pertambahan aktiva tetap $15,59 \%$ dari total aset yang digunakan pada perusahaan industri manufaktur yang menjadi sampel.

\section{Keputusan Pendanaan (X2)}

Indikator rasio total hutang terhadap total ekuitas (X2.1) meningkat terus dari tahun 2014 sebesar 1,25 ke tahun 2015 dan tahun 2016 masing-masing 1,43 dan 1,51 kemudian turun di tahun 2017 dan 2018 masing-masing 1,45 dan 1,20. Rata-rata selama empat tahun sebesar 1,37, ini memperlihatkan bahwa perbandingan jumlah hutang dengan ekuitas dalam perusahaan yang dikenal dengan struktur modalnya sebesar 1,37 besarnya hutang dibandingkan besarnya ekuitas.

Indikator jumlah total hutang terhadap total asset (X2.2) naik dari tahun 2014 sebesar 0,41 ke tahun 2015 senilai 0,44, tahun 2015 ke tahun 2016 naik lagi menjadi 0,50 kemudian turun di tahun 2017 menjadi 0,42 namun naik kembali di tahun 2018 sebesar 0,68. Rata-rata selama empat tahun sebesar 0,49. Ini menunjukkan bahwa total asset yang pendanaannya berasal dari total hutang sebesar 49\% untuk perusahaan industri manufaktur yang menjadi sampel.

Indikator total hutang jangka panjang terhadap total ekuitas (X2.3) menunjukkan fluktuasi tahunan dengan hasil menurun dari tahun 2014 sebesar 0,26 ke tahun 2015 senilai 0,17 , tahun 2015 ke tahun 2016 naik dari 0,17 menjadi 0,38 kemudian turun di tahun 2017 dan 2018 masing-masing menjadi 0,26 dan 0,22. Rata-rata selama empat tahun sebesar 0,26. Ini menunjukkan bahwa komposisi total hutang jangka panjang terhadap total ekuitas sebesar $26 \%$, atas perusahaan industri manufaktur yang menjadi sampel.

\section{Kebijakan Deviden (X3)}

Indikator rasio nilai deviden per lembar saham terhadap laba per lembar saham (X3.1) meningkat terus dari tahun
2014 sebesar 5,59 ke tahun 2015 dan tahun 2016 masing-masing 5,99 dan 11,84 kemudian turun di tahun 2017 menjadi 4,40 kemudian naik di 2018 menjadi 4,40. Ratarata selama empat tahun sebesar 5,99, ini memperlihatkan bahwa nilai deviden per lembar saham dibagi terhadap laba per lembar saham sebesar 5,99 kali untuk perusahaan industry manufaktur yang menjadi sampel pada penelitian. Indikator deviden per lembar saham terhadap harga penutupan saham (X3.2) naik dari tahun 2014 sebesar 0,08 ke tahun 2015 dan tahun 2016 berturut-turut senilai 0,12 , dan 0,19 kemudian turun di tahun 2017 menjadi 0,12 namun naik kembali di tahun 2018 sebesar 0,18 . Rata-rata selama empat tahun sebesar 0,14 . Ini menunjukkan bahwa nilai deviden per lembar saham terhadap harga penutupan saham sebesar 14\% untuk perusahaan industri manufaktur yang menjadi sampel.

\section{Tata Kelola (X4)}

Indikator jumlah saham yang dimiliki institusi terhadap jumlah saham yang beredar (X4.1) meningkat terus dari tahun 2014 sebesar 72,66 ke tahun 2015 sampai dengan tahun 2017 masing-masing 72,78 ke 74,63, dan 89,76 turun di tahun 2018 menjadi 84,95. Rata-rata selama empat tahun sebesar 84,00, ini memperlihatkan bahwa jumlah saham yang dimiliki institusi masih sangat dominan yaitu sebesar $84,00 \%$ dari total saham yang beredar. Indikator jumlah saham yang dimiliki manajer terhadap jumlah saham yang beredar (X4.2) naik terus dari tahun 2014 sebesar 2,41 ke tahun 2015, 2016, 2017, dan 2018 berturutturut senilai 2,96, ke 3,00, ke 3,13, dan 3,14. Rata-rata selama empat tahun sebesar 2,93 .

Ini menunjukkan bahwa jumlah saham yang dimiliki manajer semakin tahun semakin meningkat dengan rata-rata 2,93\% dari jumlah saham yang beredar untuk perusahaan industri manufaktur yang menjadi sampel. Indikator proporsi dewan 
komisaris suatu perusahaan (X4.3) menunjukkan jumlah yang tetap selama empat tahun berturut-turut yaitu sebesar 0,26 atau sebesar $26 \%$ pada perusahaan industri manufaktur yang menjadi sampel.

\section{Nilai Perusahaan (Y)}

Indikator rasio total asset dikurangi total ekuitas ditambah jumlah lembar saham beredar dikali harga penutupan saham terhadap total aset (Y.1) meningkat dari tahun 2014 sebesar 1,80 ke tahun 2015 sebesar 2,04 kemudian turun di tahun 2016 sebesar 1,42 dan naik di tahun 2017 dan tahun 2018 berturut-turut menjadi 2,30 dan 2,73. Rata-rata selama empat tahun sebesar 2,06, ini memperlihatkan bahwa pasar asset sebesar 2.06 kali dibanding total asset yang digunakan untuk perusahaan industri manufaktur yang menjadi perusahaan sampel.

Indikator nilai buku saham terhadap total ekuitas (Y.2) naik dari tahun 2014 sebesar 4,63 ke tahun 2015 senilai 5,19, dan turun di tahun 2015 menjadi 1,73 kemudian naik di tahun 2016 menjadi 7,63 dan turun lagi di tahun 2018 menjadi 6,84. Rata-rata selama empat tahun sebesar 5,20. Ini menunjukkan bahwa nilai buku saham terhadap total ekuitas sebesar 5,20 kali untuk perusahaan industri manufaktur yang menjadi sampel. Indikator harga pasar per lembar saham terhadap laba per lembar saham beredar (Y.3) menunjukkan penurunan dari tahun 2014 sebesar 13,36 ke tahun 2015 senilai 12,74 kemudian naik di tahun 2016 menjadi 32,64 kemudian turun lagi di tahun 2017 menjadi 17,33 dan 2018 naik lagi menjadi 28,47. Rata-rata selama empat tahun sebesar 20,91. Ini menunjukkan bahwa harga pasar per lembar saham terhadap laba perlembar saham beredar sebesar 20,91\%, atas perusahaan industri manufaktur yang menjadi sampel.

\section{Analisis Confirmatory Variable Keputusan Investasi (X1)}

Nilai buku aktiva tetap terhadap nilai buku total aktiva (X1.1) menghasilkan estimasi atau loading factor 0,531 dengan taraf signifikan 0,000 yang berarti bahwa indicator X1.1 ini layak menjadi indicator atas variable tersebut. Indikator jumlah lembar saham beredar dikali harga penutupan saham terhadap total ekuitas (X1.2) menghasilkan estimasi atau loading factor 0,866 dengan taraf signifikan 0,000 yang berarti bahwa indikator X1.2 ini layak menjadi indikator atas variable tersebut.

Indikator nilai buku aktiva dikurangi nilai buku ekuitas ditambah jumlah lembar saham beredar dikali harga penutupan saham terhadap total aset (X1.3) menghasilkan estimasi atau loading factor 0,703 dengan taraf signifikan 0,000 yang berarti bahwa indikator X1.3 ini layak menjadi indikator atas variable tersebut. Begitu pula indikator pertambahan nilai buku aktiva pada tahun tertentu terhadap total aset (X1.4) menghasilkan estimasi atau loading factor 1,000 dengan taraf signifikan 0,000 yang berarti bahwa indikator X1.4 ini layak menjadi indikator atas variable sekaligus sebagai indicator penentu pada variable keputusan investasi.

\section{Keputusan Pendanaan (X2)}

Nilai total hutang terhadap nilai total ekuitas (X2.1) menghasilkan estimasi atau loading factor 0,509 dengan taraf signifikan 0,000 yang berarti bahwa indicator X2.1 ini layak menjadi indicator atas variable tersebut. Indikator total hutang terhadap total aset (X2.2) menghasilkan estimasi atau loading factor 0,363 dengan taraf signifikan 0,000 yang berarti bahwa indikator X2.2 ini layak menjadi indikator atas variable tersebut. Indikator total hutang jangka panjang terhadap total ekuitas (X2.3) menghasilkan estimasi atau loading factor 0,693 dengan taraf signifikan 0,000 yang 
berarti bahwa indikator X2.3 ini layak menjadi indikator atas variable tersebut.

Begitu pula indikator total hutang terhadap jumlah saham beredar dikali harga penutupan saham (X2.4) menghasilkan estimasi atau loading factor 1,000 dengan taraf signifikan 0,000 yang berarti bahwa indikator X1.4 ini layak menjadi indikator atas variable sekaligus sebagai indikator penentu pada variabel keputusan pendanaan. Di antara keempat indikator terdapat satu indikator total hutang terhadap jumlah saham beredar dikali harga penutupan saham (X2.4) sebagai penentu atau dominan menentukan variabel keputusan.

\section{Kebijakan Deviden (X3)}

Indikator nilai deviden per lembar saham terhadap nilai laba per lembar saham (X3.1) menghasilkan estimasi atau loading factor 0,843 dengan taraf signifikan 0,000 yang berarti bahwa indikator X3.1 ini layak menjadi indikator atas variabel tersebut. Indikator deviden per lembar saham terhadap harga penutupan saham (X3.2) menghasilkan estimasi atau loading factor 1,000 dengan taraf signifikan 0,000 yang berarti bahwa indikator X3.2 ini layak menjadi indikator sekaligus sebagai indicator penentu atas variable tersebut. Diantara kedua indikator terdapat satu indikator deviden per lembar saham harga penutupan saham (X3.2) sebagai penentu atau dominan menentukan variabel keputusan.

\section{Tata Kelola Perusahaan (X4)}

Indikator kepemilikan institusional (X4.1) menghasilkan estimasi atau loading factor 0,235 dengan taraf signifikan 0,000 yang berarti bahwa indikator X4.1 ini layak menjadi indikator atas variable tersebut. Indikator kepemilikan manajer (X4.2) menghasilkan estimasi atau loading factor 1,000 dengan taraf signifikan 0,000 yang berarti bahwa indikator X4.2 ini layak menjadi indikator sekaligus sebagai indicator penentu atas variable tersebut. Indikator proporsi dewan komisaris pada perusahaan (X4.3) menghasilkan estimasi atau loading factor 0,231 dengan taraf signifikan 0,000 yang berarti bahwa indikator X4.3 ini layak menjadi indikator atas variabel tersebut.

Indikator jumlah dewan komite indikator kepemilikan institusional (X4.1) menghasilkan estimasi atau loading factor 0,235 dengan taraf signifikan 0,000 yang berarti bahwa indikator X4.1 ini layak menjadi indikator atas variable tersebut. Indikator kepemilikan manajer (X4.2) menghasilkan estimasi atau loading factor 1,000 dengan taraf signifikan 0,000 yang berarti bahwa indikator X4.2 ini layak menjadi indikator sekaligus sebagai indicator penentu atas variable tersebut audit (X4.4) menghasilkan estimasi atau loading factor 0,201 dengan taraf signifikan 0,000 yang berarti bahwa indikator X4.4 ini layak menjadi indikator sekaligus sebagai indicator penentu atas variable tersebut. semua indikator pada variable tata kelola indikator kepemilikan institusional (X4.1) menghasilkan estimasi atau loading factor 0,235 dengan taraf signifikan 0,000 yang berarti bahwa indikator X4.1 ini layak menjadi indikator atas variable tersebut.

\section{Nilai Perusahaan (Y)}

Indikator nilai buku total aktiva dikurangi nilai buku ekuitas ditambah nilai saham beredar dikali harga penutupan saham terhadap total asset (Y.1) menghasilkan estimasi atau loading factor 0,376 dengan taraf signifikan 0,000 yang berarti bahwa indikator Y.1 ini layak menjadi indikator atas variable tersebut. Indikator nilai pasar saham berupa jumlah lembar saham dikali harga penutupan saham terhadap total ekuitas (Y.2) menghasilkan estimasi atau loading factor 1,000 dengan taraf signifikan 0,000 yang berarti bahwa indikator Y.2 ini layak menjadi indikator 
sekaligus sebagai indikator penentu atas variabel tersebut.

Indikator penutupan saham terhadap laba per lembar saham yang dikenal dengan price earning ratio (Y.3) menghasilkan estimasi atau loading factor 0,371 dengan taraf signifikan 0,000 yang berarti bahwa indikator Y.3 ini layak menjadi indikator atas variable tersebut. Indikator nilai pasar ekuitas ditambah total debt terhadap nilai buku ekuitas ditambah total debt yang dikenal dengan Tobin's Q (Y.4) menghasilkan estimasi atau loading factor 0,221 dengan taraf signifikan 0,000 yang berarti bahwa indikator Y.4 ini layak menjadi indikator atas variable tersebut. Semua indikator pada variabel nilai perusahaan layak menjadi indikator atas variabel tersebut dan indikator nilai pasar saham beredar dikali harga penutupan saham terhadap total ekuitas (Y.3) sebagai penentu atau dominan menentukan variabel nilai perusahaan.

\section{KESIMPULAN DAN SARAN}

Berdasarkan hasil penelitian dan pembahasan, maka kesimpulan yang dapat ditarik yaitu:

1. Keputusan investasi mempunyai pengaruh negatif dan tidak signifikan terhadap nilai perusahaan. Berarti keputusan investasi yang diambil manajer belum layak dalam menciptakan nilai bagi para pemegang saham perusahaan.

2. Keputusan pendanaan mempunyai pengaruh positif dan tidak signifikan terhadap nilai perusahaan. Artinya, keputusan yang diambil manajer sudah layak dalam menentukan penciptaan nilai bagi perusahaan walaupun sangat belum signifikan.

3. Kebijakan deviden mempunyai pengaruh negatif dan signifikan terhadap nilai perusahaan. Artinya perusahaan telah menerapkan kebijakan yang cukup layak untuk menciptakan nilai bagi para investor dan pemegang saham perusahaan.

4. Tata kelola mempunyai pengaruh positif dan tidak signifikan terhadap nilai perusahaan. Ini berarti tata kelola belum dijalankan sebagai sistem yang layak dalam menghasilkan nilai saham total aktiva, nilai saham total ekuitas dan nilai pasar perusahaan.

Adapun yang menjadi saran dalam penelitian ini yaitu:

1.Perusahaan harus mampu mengambil keputusan investasi yang tepat, sehingga layak dalam menciptakan nilai bagi para pemegang saham perusahaan. Penerapan kebijakan investasi lebih diarahkan pada aktiva tetap berupa barang modal yang mampu meningkatkan produksi.

2. Pengambilan keputusan pendanaan oleh manajer selayaknya dilakukan dengan mengupayakan terjadi trade off hutang dan modal sendiri dalam rangka penciptaan nilai bagi perusahaan.

3. Kebijakan deviden yang diambil oleh perusahaan harus mampu meminimalkan konflik keagenan antara manajer dengan para pemegang saham.

4. Menerapkan tata kelola yang baik dalam mengarahkan dan mengendalikan kegiatan bisnis perusahaan, sehingga memberikan pengaruh terhadap nilai perusahaan

\section{UCAPAN TERIMA KASIH}

Penulis ingin mengucapkan terima kasih kepada semua pihak yang telah banyak membantu dalam penyusunan penelitian ini sehingga dapat terpublikasi. Semoga penelitian ini dapat berguna bagi masyarakat.

\section{DAFTAR PUSTAKA}

Ahmed Ali H., J., 2009. Revisiting Capital Structure Theory: A Test of Packing Oeder and Static Order 
Trade-of Model from Malaysian Capital Market. International Research Journal of Finance and Economics, Vol. 30.

Akhmad, Syakhroza. 2012. Mekanisme Pengendalian Internal dalam melakukan Assesment terhadap Pelaksanaan Good Corporate Governance. Manajemen Usahawan Indonesia, No. 08/Th. XXXI, Agustus.

Al-Malkawi, Husam-Aldin Nizar. 2010. Determinants of Corporate Dividend Policy in Jordan: An Application of the Tobit Model. Journal of Economic \& Administrative Sciences, Vol. 23, No. 2: pp. 44-70

Alfredo, David K. 2014. Multinational Business Finance. Addison, Wesley Publishing Company, California.

Amihud, Y. dan K. Li. 2011. The Declining Information Content of Dividend Announcements and the Effect of Institutional Holdings. Journal of Financial and Quantitative Analysis, Vol. 41, pp. 637-660.

Beiner Stefen, dkk. 2004. An Integrate Framework of Corporate Governance and Firm Valuation Evidence Switzerland.

Hasnawati Sri. 2010. Pengaruh Keputusan Investasi, Keputusan Pendanaan, dan Kebijakan Dividen Terhadap Nilai Perusahaan Publik (Di Bursa Efek Jakarta). Disertasi, tidak dipublikasikan. Universitas Padjadjaran Bandung.
Hermindito Ka'aro. 2010. Simultaneous Analysis of Corporate Invesment, Dividend, and Finance: Empirical Evidence Under High Uncertainty. The Journal of Accuonting, Management, and Economics Research. Vol 3 No. 1, February 2010: 1-17.

Horne, Van James C., and Wachowicz, Jhon M. 2007. Prinsip-prinsip Manajemen Keuangan. Edisi Kesembilan. Edisi Indonesia. Jakarta: Salemba Empat.

Husnan Suad dan Pujiastuti Enny. 2012. Dasar-dasar Manajemen Keuangan. Edisi Ketiga UPP AMP Yogyakarta: YKPN.

Sari Kusumastuti, Supatmi, Sastra P. 2007. Pengaruh Board Diversity Terhadap Nilai Perusahaan dalam Perspektof Corporate Governance. Jurnal Akuntansi dan Keuangan. Vol. 9 No. 2, Nopember 2007 Hal 88-98, Jakarta.

Sugiarto. 2008. Kebijakan Struktur Modal: Kajian PerusahaanPerusahaan Terbuka Non Keuangan di Indonesia yang dikontrol Keluarga. Disertasi. Program Doktor Ilmu Manajemen, Institut Bisnis dan Informatika Indonesia (IBII), Jakarta (Tidak dipublikasi).

Sugiarto. 2009. Good Corporate Governance, Mampukah Meningkatkan Kinerja Perusahaan. Jurnal Akuntabilitas, Vol 6 No. 1 September 2009, halaman 34 - 46 Jakarta.

Sugiarto. 2008. Kebijakan Struktur Modal: Kajian Perusahaan- 


\section{Perusahaan Terbuka Non Keuangan di Indonesia yang dikontrol Keluarga. Disertasi. Program Doktor Ilmu Manajemen, Institut Bisnis dan Informatika Indonesia (IBII), Jakarta (Tidak dipublikasi).}

Sugiyono. 2012. Metodologi Penelitian.

Jakarta: Penerbit Gunung Agung.

Suhendra, Bustanil. 2005. Manajemen

Keuangan. Jakarta: Bina Rupa Aksara.

Untung Wahyudi. 2008. Analisis Kebijakan Keuangan Perusahaan. Jakarta.: Elex Media Komputindo. 